\title{
Analysis of Policy Change Relating to Presidential Regulation No.19 year 2016 on Health Insurance became Presidential Regulation No.28 year 2016 on Health Insurance
}

\author{
*Julian Simanjuntak, **Amal Chalik Sjaaf \\ * Faculty of Public Health Universitas Indonesia \\ ** Department Health Administration and Policy, Faculty of Public Health Universitas Indonesia \\ Email: juliansimanjuntak7@gmail.com
}

\begin{abstract}
The rapid change from presidential regulation no.19 year 2016 on health insurance into presidential regulation no. 28 year 2016 on health insurance get a big attention. This research was purposed to analyze about health insurance policy which changed very quickly. It changed from presidential regulation no.19 year 2016 into presidential regulation no. 28 year 2016 on health insurance. The researcher used qualitative methods. The analysis from the input processing and output showed that the change of presidential regulation is a responsive form from president when he looked public rejection response for the increase of fee. The president extended it through the department of health affairs. In terms of inputs, the resources of this policy change are still very limited, while at the stage of the process there is still a lack of cross-sector coordination with related institutions and difficulties in getting the materials needed in the discussion. Presidential Regulation No.28 of 2016 on Health Insurance that became the output in this change is considered to be able to accommodate the demand of the people but the changes are not in accordance with the actuary calculations. This change of presidential regulation not yet affected to appropriate the fee adequacy on BPJS Implementation. The department of health affairs as a leader of health sector was recommended to increase the cross-sectoral coordination which can manifest the better product of health policy and to complete the policy instrument that yet to be determined. It also used to be concern from the department of health affairs, DJSN and BPJS which explained the increase of fee must be offset by a quality improvement rather than the implementation of national health insurance.
\end{abstract}

Keywords: change, policy, presidential

\begin{abstract}
Abstrak.
Perubahan Peraturan Presiden No.19 Tahun 2016 tentang Jaminan Kesehatan menjadi Peraturan Presiden No.28 Tahun 2016 tentang Jaminan Kesehatan yang sangat cepat menjadi sorotan yang mencolok. Tujuan penelitian ini untuk menganalisis perubahan yang begitu cepat tentang kebijakan jaminan kesehatan Peraturan Presiden No.19 Tahun 2016 tentang Jaminan Kesehatan menjadi Peraturan Presiden No.28 Tahun 2016 tentang Jaminan Kesehatan dengan menggunakan pendekatan kualitatif. Berdasarkan analisis bahwa dalam proses input, proses dan output, perubahan Peraturan Presiden ini merupakan bentuk responsif Presiden melalui lembaga pemerintah Kementerian Kesehatan dengan melihat respon penolakan masyarakat akan kenaikan iuran. Dari segi input, sumber daya perubahan kebijakan ini masih sangat terbatas, sementara pada tahapan proses masih kurangnya kordinasi lintas sektoral dengan pihak terkait dan kesulitan dalam mendapatkan bahan-bahan yang dibutuhkan dalam pembahasan. Peraturan Presiden No.28 Tahun 2016 tentang Jaminan Kesehatan yang menjadi output dalam perubahan ini dinilai sudah mampu mengakomodir permintaan rakyat akan tetapi perubahan yang ada tidak sesuai dengan perhitungan aktuaris. Dengan adanya perubahan Peraturan Presiden ini berdampak belum memadainya kecukupan iuran dalam penyelenggaraan BPJS. Peran Kementerian Kesehatan sebagai leader dalam regulasi bidang kesehatan disarankan dapat meningkatkan koordinasi lintas sektoral untuk dapat mewujudkan produk kebijakan kesehatan yang lebih baik serta melengkapi instrument kebijakan yang belum ditetapkan, serta untuk menjadi perhatian sektor terkait Kementerian Kesehatan, DJSN dan BPJS Kesehatan bahwa kenaikan iuran harus dapat diimbangi dengan peningkatan kualitas daripada penyelenggaraan jaminan kesehatan nasional
\end{abstract}

Kata kunci: perubahan, kebijakan, peraturan presiden

\section{INTRODUCTION}

National law (UU) No. 40 Year 2004 on National Social Security System (SJSN) is the effort of the Republic of Indonesia in the terms of legislation in ensuring the fulfillment of the right to health for the entire population. The law states that government is responsible for the (1) availability of services, (2) access to facilities and information, (3) equal resources and (4) striving for appropriateness and affordability in the health sector. Furthermore, the government is also responsible for the implementation of health insurance through national social health insurance system for every citizen. 
The continuation of National Law No. 40 Year 2004 on SJSN is the issuance of Law of the Republic of Indonesia No. 24 Year 2011 on Social Security Administration Body (BPJS). The law explains that BPJS consists of BPJS-Health and BPJS-Employment. BPJS-Health is a government policy program to organize National Health Insurance (JKN). BPJSHealth has been implemented since January 1, 2014.

In implementing the SJSN and BPJS Law, the government implements its policies through Government Regulations and Presidential Regulations, one of which is Presidential Regulation No.12 Year 2013 on Health Insurance. This regulation has three amendments; the first amendment becomes Presidential Regulation No. 111 Year 2013, the second amendment becomes Presidential Regulation No.19 Year 2016 on Health Insurance and the third amendment becomes Presidential Regulation No.28 Year 2016 on Health Insurance.

The second amendment into Presidential Regulation No.19 Year 2016 is conducted with the spirit of improving the conditions of National Health Insurance implementation; among others, to meet the adequacy of dues, arrange membership, regulate fines and set up fraud prevention. However, only within a period of not more than 30 (thirty) days of the Presidential Regulation implementation, this regulation was changed to Presidential Regulation No. 28 Year 2016. This change makes Presidential Regulation No.19 Year 2016 on Health Insurance has not had time to be implemented.

In the system theory explained by Easton, a policymaking process begins with an input process that describes all demands, resources and support from environments that require problem-solving solutions. Then, all the variables present in the input process will be processed into another process to create a policy. In this process, there would be dynamics and interaction of various stakeholders involved (Auguba, 2013) and produce output in the form of public policy as a solution.

A policy analysis is necessary to see why such policy changes occured so quickly. Therefore, this study aims to analyze the rapid changes in JKN policy; Presidential Regulation No.19 Year 2016 on Health Insurance becomes Presidential Regulation No. 28 Year 2016 on Health Insurance.

\section{METHOD}

This research is a policy research using qualitative approach method by collecting data deeply through informants with in-depth interview method and literature study. This study delves deeper and analyzes changes in JKN policies; Presidential Regulation No. 19 Year 2016 on Health Insurance becomes Presidential Regulation No. 28 Year 2016 on Health Insurance. This research was conducted in May until June 2016 in DKI Jakarta Province. After all the data collected and processed, then the next stage was to perform data analysis. At the stage of data analysts, testing of research results was conducted using triangulation which is the validity-checking technique of data that utilizes something else in comparing the results of interviews on the object of research.

\section{RESULTS}

The policy change analysis of Presidential Regulation No.19 YEar 2016 on Health Insurance becomes Presidential Regulation No.28 Year 2016 on Health Insurance in the form of policy-making systems theory based on Easton, as follows:

a. Input

Inside the input variables in this study, there is a policy formulation approach as a system which consists of demands, resources and support. Demands for amendment of Presidential Regulation No.19 of 2016 on Health Insurance into Presidential Regulation No.28 of 2016 on Health Insurance is generally desired by all stakeholders. This amendment brings the hope that (1) the provision of health insurance would be accordance with the rules and regulations which have been arranged; (2) the availability of adequate budget; (3) the availability of adequate health facilities and health services; and (4) the effectiveness of coordination across sectors in preparing a public policy related to the health sector.

Support for the amendment of Presidential Regulation No.19 Year 2016 on Health Insurance into Presidential Regulation No.28 Year 2016 on Health Insurance, in this case is the Ministry of Health, has performed its function as government and initiated its change to accommodate the real needs of the community.

The resources in this Presidential Regulation amendment are still very limited, such as the lack of human resources, uneffective cross-sectoral coordination, the unavailability of health facilities and good health services, the public understanding of the importance of the National Health Insurance and the lack participation of health policy experts who are involved in the discussion of the initial stages only.

\section{b. Process}

Process variables describe the stages of formulating, taking or adopting alternative policy solutions which are defined as regulations or policy products which will be implemented formally. After going through the stages of interview and deepening research, the phase of shifting process from Presidential Regulation No.19 Year 2016 on Health Insurance into Presidential Regulation No.28 Year 2016 on Health Insurance was still lack of coordination across sectors with relevant stakeholder. Other than that, several relevant 
stakeholders found it difficult to obtain materials which should be accepted as references in the discussion phase.

The interview results with the House of Representatives Commission IX stated that the initial discussion of this amendment did not have any coordinations with the House of Representatives. The parliament sees this as a polemic which occurred in the amendment of the Presidential Regulation was not in accordance with the spirit of existing legislation of National Law No.40 Year 2004 on SJSN and National Law No.24 Year 2009 on BPJS. Therefore, the House of Representatives called the government to conduct discussions and rejected the increasing tariff rates in Presidential Regulation No.19 of 2016 on Health Insurance.

In formulating the amount of contributions, they did not use the academic research analysis by considering the calculations which use the evidance-based practice. The DJSN also seen that they did not do a detailed discussion and did not invite various stakeholders to amend this Presidential Regulation because the change is only about $\mathrm{Rp} 4.000$,-. This amendment process, according to the DJSN, only took one week on the basis of the change itself because of the community response who refused to increase the contributions for the Presidential Regulation No.19 Year 2016 on Health Insurance. The process of amending this Presidential Regulation was the President's initiative through the Ministry of Health as the initiator of the change. After obtaining an initiative permission for this Presidential Regulation amendment, the Ministry of Health as a health regulator proposed to cooperate with relevant stakeholders in drafting of the regulation.

\section{c. Output}

Output variables which is in the form of amendment of Presidential Regulation No.19 Year 2016 on Health Insurance into Presidential Regulation No.28 Year 2016 on Health Insurance. There are three main points in this amendment: (1) the change in the amount of contributions for class III that initially Rp.30.000,(thirty thousand rupiah) per month changed to Rp.25.500,- (twenty five thousand rupiah) per month, (2) the coordination of benefits and (3) the establishment of the highest salary or wage limit for the worker is Rp.8.000.000,- (eight million rupiah). The amendment of this presidential regulation has accommodated the people's demand but this change is not in line with actuary calculations. The majority of informants said that with the amendment of this Presidential Regulation, the stable dues sufficiency has not been fulfilled and health services have not been implemented in plenary or universal coverage. The result of this Presidential Regulation amendment shows that the government still has not seriously handled the optimal National Health Security.

\section{DISCUSSION}

A good public policy could turn demands into a policy, in which case a good healthcare policy is required, sufficient for existing funds, maximum perceived benefits and good quality health services. A system should be able to manage and resolve the contradiction or conflict that is in a demand/input. Therefore, the system should be built on the elements that support which depends on the interaction between various subsystems. Then, a system would protect itself through three things, namely producing satisfactory output, relying on bonds rooted in the system itself and threatening by using force (authority). In the input section of the policy formulation approach as a system, there are demands, resources and support.

The demand for health insurance policies is raised by various stakeholders, including communities, governments, or the organizers of BPJS-Health in accordance with what they want or the values they have. Such demands arise when individuals or groups articulate them through a particular interest or agency group to the government. Ministry of Health as a resource who helps the government would respond to existing demands or made demands. While support refers to the support conveyed by the majority in the health system.

Policy formulation is a formal process of taking or adopting alternative policy solutions that are defined as a regulation or policy product to be implemented. The process of policy analysis according to Dunn, is done through four stages: problem formulation, forecasting, recommendation, monitoring and evaluation. In each of these stages should involves various concerned sectors to formulate the best policy. However, in the preparation of the Presidential Regulation amendment initiated by the Ministry of Health did not illustrate a good cross-sectoral cooperation.

The amendment of Presidential Regulation No.19 Year 2016 on Health Insurance into Presidential Regulation No.28 Year 2016 on Health Insurance is a responsive form of the President who sees the community's rejection response to the increased fees into Presidential Regulation No.19 Year 2016 on Health Insurance. In the amendment process, it should be in accordance with the theory of forming a good policy as mentioned in the policy formation process through the stages of problem structuring, forecasting, recommendation, monitoring, and evaluation (Ayuningtyas, 2014). In addition, Yulianti (2010) also stated that the policy formulation stage is a process which is done in real by involving the stakeholders to produce a series of actions in solving public problems through identification and analysis of alternatives and not apart from the values that affect the actions of stakeholders' interests in the process. 
Policy making is determined by recommendations from various parties, in this case are DJSN, Ministry of Health, BPJS Health, House of Representatives, Ministry of Justice and Human Rights and Cabinet Secretariat, which could provide information about the some benefits and impacts that may occur from some policy alternatives that have been prepared comprehensively. According to DJSN, the decrease of about Rp.4.000,- (four thousand rupiah) is a small and meaningless nominal; but assuming if the difference of approximately Rp.4.000,- (four thousand rupiah) is calculated with all participants which are not recipients of wages, the result is definitely a very big fund. So, the rules formed are good rules and have a target, either short term or long term.

The implementation of good national health insurance should be supported by strong policy instruments. In this context, all the specific legislation on national health insurance should be reduced to one level below it and must be implemented. Yet, there are still many legislations which until now have not been made the derivative regulation. Presidential Regulation No.28 Year 2016 on Health Insurance as the output of public policy will clearly help the third class participants in terms of payment of contributions. However, we would not be able to turn a blind eye to the adequacy of funds available for the benefits of all membership and sustainability of the BPJS-Health implementation where the increase fees would be offset by improved service quality.

Based on the academic research, the suitability of the determined contributions needs to be balanced with the improvement of service quality and the adequate distribution of medicines and service facilities. In addition, with the existence of adequate contributions, the payment to health facilities and health personnels could be balanced straight; so as to increase the professionalism of health workers and impact on quality health services. If the system continues to be properly monitored from the withdrawal of contributions, the proper utilization of tuition fees, supervision of the use and management of existing funds then the public's understanding of the National Health Insurance will turn into a good quality product. Meanwhile, if the funds sufficiency is not met, then automatically the driving wheel of National Health Insurance will experience barriers felt by all stakeholders.

\section{CONCLUSION}

According to the discussion of policy amendment analysis of Presidential Regulation No.19 Year 2016 on Health Insurance into Presidential Regulation No.28 Year 2016 on Health Insurance, the following conclusions could be drawn:

1. The main amendments in Presidential Regulation No.19 Year 2016 on Health Insurance into
Presidential Regulation No.28 YEar 2016 on Health Insurance are changes in (1) the provision of class III contribution fee which is refunded from Rp.30.000,- to Rp.25.500,-, determination the highest wage limit of the wage earners of Rp.8.000.000,- and (3) the coordination of benefits provided.

2. Rapid change in Presidential Regulation No.19 Year 2016 on Health Insurance became Presidential Regulation No.28 Year 2016 on Health Insurance due to the rejection public response and the accommodating president through the Ministry of Health as regulator of the health sector.

3. Inadequate use of space for participation in the preparation process of Presidential Regulation No.19 Year 2016 on Health Insurance became Presidential Regulation No.28 Year 2016 on Health Insurance due to lack of information available to each sector related to the consequencse of rapid amendment of this Presidential Regulation.

4. The overall process of preparing Presidential Regulation No.19 Year 2016 on Health Insurance into Presidential Regulation No.28 Year 2016 on Health Insurance has not yet reflected a policy which solve health insurance problem. The existence of the reduction fees does support the people when viewed as the dues amount that are lowered. However, it has not solved the problem related to the adequacy of contributions in accordance with the calculations using academic studies and potentially hampering the sustainability of the national health insurance program.

5. Cooperation across sectors is still not seen closely in the policy formulation because there are still differences and clashes in views where each stakeholder does not want to try to know the views of some other sectors.

6. There is no adequate problem assessment in the issue of refusal of contribution increase in Presidential Regulation No.19 Year 2016 on Health Insurance.

7. Regardless of the dues determined, if there are no balancing measures such as system improvements in the implementation of BPJS from the controlling system of supervision, control, evaluation and improvement; the system will not solve the problem of national health insurance.

Based on the results, discussion and conclusion above, there could be recommended as follows:

1. As a step to improve cross-sector coordination and community participation, in every process of legal product preparation which can be done with advocacy or assistance to community groups should be conducted by experts, universities, community organizations and government. This activity aims to increase the capacity of all 
elements in organizing the group and its importance as a good public policy prerequisite.

2. The government, in this case the Ministry of Health, as the regulatory leader in the health sector and the DJSN should involve the participation of all relevant stakeholders and communities who are directly affected by the implementation of a regulation. The involvement is from the planning phase to the evaluation phase of the regulation implementation, not only at the discussion phase or when there is a polemic.

3. Urgency of academic research in the process of formulating regulations need to be supported by adequate human resources, sufficient funds and more time; so that the result of academic research is worthy of reference in the process of drafting a regulation.

4. To achieve a better national health insurance, support is needed not only from the government, parliament or policy experts, but also the public understanding of the importance of health insurance needs so that people could invest in health products.

5. Ministry of Health, DJSN and BPJS-Health should note that the increase in contributions/fees must be balanced with the improvement of quality in the implementation of national health insurance.

6. Ministry of Health as a leader in the health sector should complement the policy instruments which have been issued and regulated to continuing the quality improvement in the field of health.

7. BPJS-Health should be able to focus on increasing organizing and be more creative to cover the shortage of existing dues by the membership and exploring the existing potentials, such as coordination of benefits (COB) so that the wheel of the organization could keep moving and achieve good quality service.

\section{REFERENCES}

A Achmadi, U. F. (2008). Horison Baru Kesehatan Masyarakat di Indonesia. Jakarta: Rineka Cipta.

Afrizal. (2015). Metode Penelitian Kualitatif : Sebuah Upaya Mendukung Penggunaan Penelitian Kualitatif dalam Berbagai Disiplin Ilmu. Jakarta: Rajawali Press.

Anderson, J. E. (1975). Public Policy Making. Praeger.

Anderson, J. E. (2006). Public Policy Making (Vol. 6). Boston: Mifflin.

Anna, L. K. (2016, April 14). Kompas. Dipetik April 20, 2016, dari http://health.kompas.com/read/2016/04/14/130000823/Klaim.Be robat.BPJS.Kesehatan.Lebih.Besar.dari.Penerimaan.Iuran

Auguba, M. K. (2013). Grounding With People : Participatory Policy Making in the Context of Contitusion Review in Ghana. Journal of Politics and Law , 99-110.

Ayuningtyas, D. (2014). Kebijakan Kesehatan : Prinsip dan Praktik. Jakarta: Rajawali Press.

Ayuningtyas, D. (2014). Kebijakan Kesehatan dan Praktik. Jakarta: Rajawali Pers.

Azwar, A. (1996). Pengantar Administrasi Kesehatan . Jakarta: Binarupa Aksara.

Bungin, B. (2012). Analisis Data Penelitian Kualitatif. Jakarta: Raja
Grafindo Persada.

Dunn, W. N. (2013). Pengantar Analisis Kebijakan Publik. Yogyakarta: Gadjah Mada University Press.

Easton, D. (1965). A Framework For Political Analysis. New Yorl: Englewood Cliffs.

Easton, D. (1965). A Systems Analysis of Political Life . New York: Jhon Wiley.

Ekowati, M. R. (2009). Perencanaan, Implementasi dan Evaluasi Kebijakan atau Program (suatu kajian teoritis dan praktis). Surakarta: Pustaka Caraka.

Gordon I, J. L. (1977). Perspectives on Policy Analysis . Germany: Public Administration Bulletin.

Handoyo. (2016, Maret 18). Dipetik April 14, 2016, dari http://nasional.kontan.co.id/news/dpr-minta-kenaikan-iuranbpjs-ditunda

K. Buse, M. N. (2005). Making health policy. London: Open University Press.

Kettl, D. F. (1996). Governing at the Millenium . San Francisco: Jossey Bass.

KOLTKO-RIVERA, M. (2006). Rediscovering the later version of Mallow's hierarchy of needs: Self-transcendence and oppurtinities for theory, research, and unification. Reviem of General Psycholgy , 302 - 317.

Lajh, U. S. (2012). Good Governance ini the Slovenian Employment and education Policy Fields : Myth or reality. Romanian Journal of Political Science, 77-102.

Nawawi, I. (2009). Public Policy, Analisis Strategis, Advokasi dan Praktek. Jakarta: Putra Media Nusantara.

Nugroho, R. (2011). Public Policy. Jakarta: Elex Media Komputindo.

Nugroho, R. (2014). Public Policy. Jakarta: Elex Media Komputindo.

Parson, W. (2005). Public Policy. London: Kencana Prenadamedia Group.

PBB. (1948). Deklarasi Universal Hak - Hak Asasi Manusia. Genewa. Sjahrir. (2008). Pikiran Politik. Bandung: Citra Aditya Bhakti.

Suharto, E. (2005). Analisis Kebijakan Publik ; Panduan Praktis Mengkaji Masalah dan Kebijakan Sosial. Bandung: Alfabeta.

Terry, G. R. (2009). Prinsip-Prinsip Manajemen. Jakarta: Bumi Aksara.

Thabrany, H. (2016, April 20). Diskusi Publik Potensi Evaluasi JKN : Masalah dan Pelurusan Evaluasi. Depok, Jawa Barat, Indonesia: PKEK FKM UI.

Walt, G. (1994). Health Policy (An Introduction to Process and Power). London: Zed Books Ltd.

Winarno, B. (2012). Kebijakan Publik (Teori, Proses dan Studi Kasus). Yogyakarta: CAPS.

Winarno, B. (2007). Kebijakan Publik : Teori dan Proses. Yogyakarta: Media Pressindo.

Yulianti. (2010). Kebijakan Publik. Jakarta: Bumi Aksara. 